\title{
Chapter 9 \\ Changes in Economic Inequality in Europe and Latin America in the First Decades of the Twenty-First Century
}

\author{
Agustín Salvia
}

\begin{abstract}
This chapter contains a comparative analysis of the changes in the inequality of family income distribution in the last two decades in Latin America and Europe. The study examines the degree to which the economic-productive factors-associated with the primary income distribution-or, on the contrary, the social policies-linked to the secondary distribution-reveal structural differences in economic inequality between regions in the 2000-2017 period. Based on a wide sample of countries, the evolution of inequality is compared within and between regions. The dissimilarity of these behaviours is examined as well as how valid certain economic-institutional factors are to give an account of the changes that occurred within each region.

The chapter shows that, in the last two decades of the twenty-first century, Western Europe and Latin America have reduced their economic inequality gap, although following different paths: while inequality decreased in the majority of Latin American countries, an inverse process, although moderate, has been taking place in the majority of Europe. While both trends had national exceptions, the evidence presented helps us to deduce that it was simultaneously due to productive changes and to changes in the growth style, and to transformations in the redistributive efficiency of expenditure on social policies.
\end{abstract}

Keywords Economic inequality - Income distribution - Comparative analysis · Europe $\cdot$ Latin America $\cdot$ Structural heterogeneity

\footnotetext{
A. Salvia $(\bowtie)$

Observatorio de la Deuda Social Argentina, Universidad Católica Argentina,

Buenos Aires, Argentina

e-mail: agustin_salvia@uca.edu.ar 


\subsection{Introduction}

The international community has made considerable progress at overcoming poverty. The most vulnerable nations continue to advance in this sphere. However, inequalities and huge disparities in income distribution continue, which appear to affect economic development and social integration capacities on a global scale (UN 2015; OECD 2013; Dollar 2005).

The aim of this chapter is to perform a comparative analysis of the structural differences and changes that have taken place in income distribution in the twenty-first century thus far for a selection of countries from Latin America and Europe, as well as within each region and between both regions. The aim of this analysis is to examine the dissimilarities between certain explanatory patterns associated with the changes that have taken place in inequality. A main question to answer is to what degree productive factors associated with the primary income distribution, or social policies, associated with the secondary income distribution, reveal both structural patterns and cycle changes in economic inequality between both regions during the 2000-2017 period.

Economic literature distinguishes between, on the one hand, the sources of "primary" (or functional) income distribution (distribution of income in the capitallabour relation) and, on the other hand, the sources of "secondary" distribution (public or private transfers from rents, gifts or taxes), whose flows are in some way removed from the added value generated by the capital-labour relation and/or the country's trade balance (Krugman et al. 2008).

While economic inequality generally refers to the distribution of income or assets between individuals and groups within a country, the term also applies to aggregate inequality across territories or regions. In this regard, according to data available on income distribution-measured using the Gini index-Europe is the region with greatest distributive equity on the planet; while Latin America is one of the most unequal (Keeley 2018; World Inequality Lab 2018; OECD 2013; Dollar 2005). ${ }^{1}$

It is important to underscore that while the social policies implemented by the European welfare states have facilitated high degrees of productivity, economic prosperity and social cohesion (Moreno and Palier 2005; Moreno 2015; Guillén et al. 2016), this is not the case with Latin-American states. These, in general, are characterised by strong productive heterogeneities, segmented labour institutions and low density or regressive social security systems (CEPAL 2014; Barba Solano 2007; Barba Solano and Cohen 2011; Salvia 2015; Bárcena and Prado 2016).

In recent years a research line has opened up dedicated to the analysis of the evolution of the participation of the wealthiest families and individuals in the income distribution available per country (Atkinson et al. 2011). The main

\footnotetext{
${ }^{1}$ The Gini coefficient is a measure of income inequality in a country, but it can be used to measure any form of unequal distribution. It is a number between 0 and 1 , where 0 corresponds to perfect equality and 1 corresponds to perfect inequality.
} 
conclusion from this research is that during the twentieth century the participation of income from the wealthiest was U-shaped, reducing during the first half of the century, increasing during the second half, with the improvements being concentrated in the highest percentile of the income available in the majority of the countries analysed. Piketty (2015) summarised this process by arguing that any increase in the rate of return of capital above the economic growth rate leads to the concentration of income and, consequently, to an increase in inequality. The different authors who studied inequality provided various explanations for the concentration of income: the type of political economy, financial downturns, technological changes, globalisation, labour regulations, human capital and taxation, although there is no consensus in this regard.

The income distribution in each country is the result of the complex interaction of innumerable economic, demographic, social and institutional factors. According to the UN (2015), although the inequality in the income distribution between countries seems to be reducing, within the countries themselves it appears to be increasing. In this regard, there is increasing consensus that economic growth is not sufficient to reduce poverty if it is not inclusive or does not tend to reduce social inequalities (Keeley 2015; OECD 2013). With a view to reducing both poverty and inequality, the application of security and universal social protection policies has been recommended which also pay particular attention to the needs of the underprivileged and marginalised (ILO 2011, 2013, 2014; Dollar 2005; Barrientos and Hulme 2008; Lustig et al. 2016b).

Inequality in income distribution on a global or regional level reflects the combined effect of inequality within countries and inequality between countries or regions. In this respect, the historical evolution of inequality on a global level reveals that following a period of an increase in inequality, a reduction in the inequality within countries is recorded, but with an increase in the gap between countries. More recently, the trend has changed: inequality tends to increase within countries and to reduce between countries (Atkinson 2015). This inverted $U$-shape in the inequality between countries is usually an encouraging base which guarantees that the global distribution will show less inequality in the future. Nevertheless, following Atkinson (2015: 72-73), there are justified reasons to be wary. Firstly, while the gaps are reducing in relative terms, the absolute differences in terms of real per capita income continue to widen. Secondly, while some large countries have grown rapidly (such as China and India), many other developing countries have done so at a much slower rate.

Explaining the factors that shape the income distribution in and between countries is a complex task. With a view to examining and comparing the changes in economic inequality in societies in Europe and Latin America, as well as between both regions, the aim of this chapter is to analyse the effect of a series of underlying structural factors on the way in which said inequalities are managed, in order to understand the role played by such factors in the convergence/divergence processes within and between the regions studied. In this context, an important aspect is to be able to determine the role played by primary income distribution and secondary 
income distribution in the structuring of the inequalities in each country, between the countries from each region and in the inequalities of both regions.

In modern capitalist economies the average income level of countries is widely related to productivity and, therefore, it depends on the degree of technology and the amount of physical capital employed in production. In general, increases in productivity are accompanied by an improvement in living conditions, as long as the labour institutions, tax systems and social security systems in operation promote the redistribution of the income. Among the countries in the world there is a clear correlation between income inequality, wage and collective bargaining regimes, the existing tax level, the type of tax policy and the social expenditure of the governments. In the most unequal countries it is common to observe weak unions, flexible labour rules and few progressive taxes, which also seems to be associated with weak, restricted or regressive social security systems (ILO 2014).

Economic inequality comprises disparities in the distribution of economic income, especially the primary income distribution generated by the capital-labour relation. Moreover, public or private transfers of income-whether through social security, social and family strategies or market rents-play a relevant role in capitalist economies in the way that they reduce, offset or worsen the economic inequalities resulting from primary distribution (Keeley 2015; Atkinson 2016). ${ }^{2}$

The present work seeks to explore this argument through the presentation of an analytical outline. This outline systematises the different ways in which the economic growth model (primary income distribution) and the social policies (secondary income distribution) are associated with inequality in the distribution of household incomes. In this context, a particularly relevant goal is to assess how and in what way the different paths followed can be explained by more structural factors affecting each region-country. These factors are the productivity of the capitallabour relation (in terms of structural heterogeneity, institutional regulation models and ways in which these factors segment the labour demand), and the role of social expenditure in the gross domestic product (as an expression of the level of coverage and redistribution of the income provided by social policies).

As we will seek to demonstrate, the socio-economic differences between both regions, and their evolution to date this century ${ }^{3}$, do not necessarily coincide with the differences observed and the changes that have taken place in inequality - measured by the Gini index-within each region and between both regions. This particular behaviour which appears to describe a "convergent" development process, both on a welfare level and in terms of equity, can be more precisely explained when the average labour productivity (as an expression of the capacity of primary

\footnotetext{
${ }^{2}$ The regulatory institutions working towards correcting inequalities can be classified into two groups, according to the time at which they operate: (1) some seek to act directly—ex ante—on the source of the inequalities in the labour market; these are called pre-distributive and (2) others do it ex post, working towards reducing the inequalities generated in the labour market; these are called post-distributive (Hacker 2011; Zalakain and Barragué 2017).

${ }^{3}$ Both in terms of economic development—-measured by GDP per capita—and its effects in terms of welfare for the population — measured by poverty lines with comparable PPPs-.
} 
income distribution) is related over time on a national level to the proportion of social expenditure in the GDP of each country (as a representation of the coverage level and scope of the secondary income distribution).

In this context, firstly, the chapter analyses how different or similar the societies of both regional systems are in terms of GDP per capita, poverty and distributive inequality, as well as exploring the development paths taken by both regions in the last few decades. To do so, we examine a selection of countries from both regions, for which we were able to obtain comparable information. Secondly, assuming the presence of unequal degrees of welfare-inequity between regions-countries, the study seeks to determine the distributive changes that have occurred during the past few decades. In this regard, in order to identify the weight of the factors underlying the different paths that income distribution has taken in both regions, the average labour productivity, the level of social expenditure and its effects on inequality for each country are related. ${ }^{4}$

To this end, in order to obtain a robust descriptive classification, following the comparative method, in other words, assuming that the national systems for each economic period are theoretical analysis units, a factorial model of main components was adjusted, using stacked time windows as registers for each country considered. The analysis models applied gather data from the 2000-2017 period for 44 countries, 26 from Europe and 18 from Latin America, dividing the groups into four periods: 2000-2004, 2005-2008, 2009-2014 and 2015-2017.5

\subsection{Conceptualizations}

In recent years a growing academic concern for economic inequality has been observed, due to the concentration of wealth in increasingly smaller groups of people, families and corporations and the political implications of these processes on the functioning of democratic societies (Therborn 2013).

The study of global economic inequality focuses on "income distribution". From this perspective it is assumed that the current income of households is a key factor for the social welfare of the population. From the point of view of social scientists, the dominance of the study of monetary income distribution often jeopardises the

\footnotetext{
${ }^{4}$ The analysis of these matters, from a perspective of the factors associated with income distribution, leads us to consider a methodological strategy of comparative analysis between countries which opens up the possibility of developing theoretical formulations that transcend the borders of a society (Holt and Turner 1970). These analyses provide relevant conclusions to progress in this line of research in international comparison.

${ }^{5}$ Countries considered in Latin America: Argentina, Bolivia, Brazil, Chile, Colombia, Costa Rica, Guatemala, Mexico, Peru, Uruguay, Ecuador, El Salvador, Honduras, Nicaragua, Paraguay, Panama, Dominican Republic and Venezuela. Countries considered in Europe: Spain, Finland, France, Italy, Poland, Portugal, United Kingdom, Romania, Germany, Austria, Belgium, Bulgaria, Cyprus, Croatia, Denmark, Slovakia, Slovenia, Estonia, Greece, Hungary, Latvia, Lithuania, Malta, The Netherlands, the Czech Republic and Sweden.
} 
possibility of reaching a wider understanding of social inequalities. However, its contribution is vital to understand how the way the main source of welfare is distributed in market economies is crucial for the progress of families and the social life of people. $^{6}$

The evolution of inequality in income distribution has summoned the interest of multiple studies. Its historical global evolution has been well represented by Piketty (2014) who showed how the concentration of wealth in the global economy has grown since 1980. There is agreement that the key period of the twentieth century was marked by a reduction in the distributive inequality of the global income and that this trend reverted in recent decades, recording a new increase in the income gap between the poor and the rich. Nevertheless, the literature is not conclusive as regards determining the trend followed by income distribution between countries and regions in the world, or as regards the factors that could explain the different processes.

On the one hand, the evidence appears to confirm a cycle of relative convergence between rich and poor regions during the first decade and a half of the twenty-first century. This seems to impinge upon the continued growth toward global inequality in income distribution (Atkinson 2015; Molero Simarro 2013; Keeley 2018). However, the conclusions about the factors underlying these processes are not conclusive. On the other hand, the works that have studied the general relation existing between inequality, growth and poverty do not have a definitive response about how and to what extent the former fosters or hinders the latter two (Molero Simarro 2013).

However, at this point, the arguments tend to agree on the limitations of Kuznets' theory (1934) about the causal contribution of growth as a subsequent factor of social balance. The apparent failure of Kuznets actually reflects another problem that economists face when determining the link between inequality and growth, namely: if there is a relation, it does not seem to be direct. If it were, we could at least, in theory, calculate the growth rate of a country based on its inequality level (Keeley 2015). This topic requires further exploration, considering the particular inverse relationship there appears to be between inequality and growth - contrary to the theory of Kuznets-in the context of modern societies. In other words, both the empirical research and the main global economic organisations (OECD, IMF, WB, IDB) agree on highlighting that at least excessive inequality is not good for growth.

In particular, according to the OECD, a greater wealth gap makes low-income families invest less in education and skill-training, which affects growth by causing a decline in qualified workers. Other authors consider the effect of inequality on political and social instability (Ostry and Berg 2011). In turn, Stiglitz (2000)

\footnotetext{
${ }^{6}$ Atkinson made a special contribution to the measurement of inequality. He looked at income inequality from a non-conventional perspective, as the loss of social welfare associated with an unequal distribution of income. In other words, he considered the analysis of inequality as a foundation for policies and suggested a series of specific measures to reduce it. The final aim of Atkinson (2015) was to transform the economic analysis into political action, and to do so he recommended new ambitious policies in five areas: technology, employment, social security, distribution of capital and taxes.
} 
highlights the collusion processes linking the political sectors with the wealthy classes, achieving that the latter monopolise the majority of the economic surpluses, affecting the demand of consumer goods and distribution among the poorer classes.

But in addition to wondering if inequality affects growth, it is equally important to examine how the level of economic productivity of countries determines, conditions or influences - through different channels - the direction of both primary and secondary income distribution. ${ }^{7}$ The primary distribution of social income takes place in the production process and is determined by the way in which the added value is distributed between wages and capital, including the mixed income of the self-employed worker or professional. To change the primary distribution, marginal productivity, wages and profits of the self-employed, the businessmen or the companies must be modified. For its part, the secondary distribution of income is that which is made through rent or transfers, whether public or private. It is mainly focused on the transfers that governments make to families through the systemscontributive or non-contributive - of security or social protection, and in the public or private mechanisms of income distribution, royalties, loans or gifts.

During the last quarter of the twentieth century and the current twenty-first century, both Western Europe and Latin America have undergone profound transformations in their social structures in the context of the global changes resulting from international political-economic conditions, with different scopes and impacts depending on the way in which each society absorbed, regulated and processed these trends. The twenty-first century is a period of exhaustion, transition and redefinition of these processes. The impact of these changes on the social reproduction patterns of economic inequalities, both in direction and in magnitude, has not been sufficiently explored by the literature. While there are studies of national cases, and even, analyses based on comparisons between countries from one same region, interregional approaches that explore the factors or social processes underlying these inequalities are particularly scarce.

In the case of Europe, the region has been subjected to a double inequality effect. While the European economic integration process reduced the inequalities between nations until the first decade of the twenty-first century, the convergence was partially interrupted due to the effects of the economic and financial downturn in 2008 and the adjustment policies that greatly affected the social and welfare budgetary items (Moreno and Palier 2005; Moreno 2012; Del Pino and Rubio 2016). The impact of the recession would have, as is well-known now, consequences on the

\footnotetext{
${ }^{7}$ Apart from several exceptions (Atkinson 1975, 2009), the studies that explore the correlation between productive capacities and interpersonal income distribution establish purely empirical relations between them (see, for example, Daudey and García-Peñalosa 2007; or Adler and Schmid 2012). In fact, in his chapter in The Oxford Handbook of Economic Inequality, Andrew Glyn concludes that there is a "need for more research to determine the causes of the oscillations in the factorial participations and to establish a connection between the personal and functional distributions of income" (Glyn 2009: 104).
} 
living conditions of Europeans, with an increase in poverty especially in countries in the south of Europe, compared to Scandinavian and Continental European countries. Therefore, within the European Union there is significant inequality across one territorial base (Del Pino and Gago 2017). However, the more or less generalised maintenance of a widespread welfare model, widely legitimised by political and social sectors, seems to restrict a greater deterioration in the context of the Great Recession (Moreno 2016; Guillén et al. 2016). ${ }^{8}$

The present work provides evidence that helps to determine the nature of the recent changes that have taken place in economic inequality between and in both regions. This task shows the different distributive roles they play, depending on the case, the sources of income, as an expression of the different roles played by labour productivity, the associated payment and social policies.

\subsection{Comparative Study of Countries from Latin America and Europe}

The general characteristics of the economic and social structure of Europe and Latin America, and their consequences on welfare, show relevant systematic differences with respect to aspects associated with their socio-productive development. These differences are not new, they developed as a result of different accumulation processes, particular economic-productive dynamics and structures, and different historical and institutionalisation processes of power relations, through socio-occupational, welfare and social protection institutions. The comparative examination during the twenty-first century to date is a relatively unexplored path of study, as is its relationship with the changes that have taken place in income distribution in each region and globally.

In order to explore these topics, the information gathered provides evidence about the different regional conditions that shape the accumulation dynamics, social intervention by the State, and income distribution in a wide sample of national systems from both regions. Through this strategy, we hope to attain a robust description of the economic inequalities for a selection of countries from Latin America and Europe, including the socioeconomic inequality processes (and the reproduction of these) in force during the first decades of the twenty-first century. While the analysis is based on the comparison of the countries in the last 18 years, it is important to highlight that the continents have significant and longstanding socioeconomic structural differences. The comparative analysis model is applied to the selected countries, gathering information for four periods: 2000-2004, 2005-2008, 2009-2014

\footnotetext{
${ }^{8}$ The European social model is a political project built around social equity, collective solidarity and productive efficiency values. In this framework, the welfare state, that is, a set of social policies aimed at improving living conditions and to achieving equal opportunities for all citizens, is the foundational institution of this model. Despite the recession, the social public expenditure in the continent represents between one fifth and one third of the GDP (Moreno 2016).
} 
and 2015-2017, using social welfare indicators based on available secondary sources.

Firstly, both for each separate period and for the total number of years considered in the sample, Table 9.1 presents the inequalities existing between the countries from each region, between regions and all the countries, and their changes over time. In particular, the following table shows data of two key welfare indicators: GDP per capita and poverty rate (less than US\$5.5 PPP-Purchasing Power Parity-). For their analysis, both regional averages and their coefficients of variation are shown. Since we are examining very unequal regions, analysis of the coefficient of variation helps to compare internal differences.

If the general averages of the economic welfare indicators are analysed, improvements can be observed both per region and for all the countries; there is even a certain tendency to converge as a result of the greater relative progress made by Latin America in poverty. However, upon analysing the coefficients of variation $(\mathrm{CV})$, the ratio between the standard deviation and the average data, for each indicator, it can be deduced that both differences between regions and between countries prevail in each region.

As regards the GDP per capita, while it has improved in both regions separately and together, the differences between Europe and Latin America persist: even when the gap reduced slightly, the average in Latin America continues to be approximately one third of the average GDP in Europe. Likewise, the coefficient of variation has reduced in Europe, but it has increased in Latin America, illustrating an increase in inequality between countries from Latin America in terms of average income per inhabitant.

Table 9.1 Evolution of welfare indicators: GDP per capita and Poverty. Latin America and Europe (Years 2000-2017)

\begin{tabular}{|c|c|c|c|c|c|}
\hline & $2000-2004$ & $2005-2008$ & 2009-2014 & 2015-2017 & Total 2000-2017 \\
\hline \multicolumn{6}{|c|}{ GDP per capita-In million US\$ $P P A$} \\
\hline Europe (26) & 27.171 & 31.059 & 31.020 & 33.616 & 30.717 \\
\hline CV EU (26) & $38.2 \%$ & $31.0 \%$ & $29.1 \%$ & $25.7 \%$ & $30.2 \%$ \\
\hline Latin America (18) & 9.193 & 10.681 & 12.186 & 13.178 & 11.349 \\
\hline CV LA (18) & $42.6 \%$ & $44.0 \%$ & $43.7 \%$ & $44.1 \%$ & $42.4 \%$ \\
\hline Total EU + AL (44) & 19.817 & 22.722 & 23.315 & 25.536 & 22.793 \\
\hline CV Total (44) & $61.5 \%$ & $56.6 \%$ & $51.9 \%$ & $49.5 \%$ & $54.1 \%$ \\
\hline \multicolumn{6}{|c|}{ Poverty (5.5 US\$ PPA)_In \% of people } \\
\hline Europe (26) & 3.6 & 3.9 & 3.6 & 2.9 & 3.9 \\
\hline CV EU (26) & $149.9 \%$ & $186.1 \%$ & $165.2 \%$ & $178.0 \%$ & $158.9 \%$ \\
\hline Latin America (18) & 45.6 & 36.6 & 28.6 & 21.6 & 34.0 \\
\hline CV AL (18) & $25.8 \%$ & $32.6 \%$ & $46.3 \%$ & $57.2 \%$ & $38.6 \%$ \\
\hline Total EU + AL (44) & 21.9 & 17.9 & 13.5 & 9.9 & 16.2 \\
\hline CV Total (44) & $103.9 \%$ & $105.5 \%$ & $115.1 \%$ & $125.9 \%$ & $109.4 \%$ \\
\hline
\end{tabular}

Source: own elaboration based on World Bank, EUROSTAT and CEPALSTAT for sample of selected countries

$C V$ Coefficient of variation, $P P A$ Purchasing power parity 


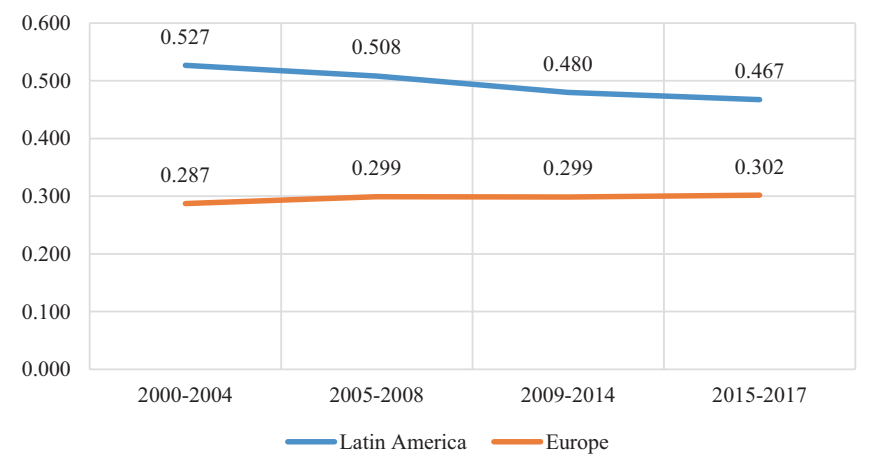

Fig. 9.1 Gini coefficient evolution. Latin America (Gini coefficient of family per capita income calculated in the distribution of people.) and Europe [Gini coefficient of equivalent income (OECD scale for normalization of household size) calculated in the distribution of people.]. (Years 2000-2017) National averages in points of the Gini Coefficient. Source: own elaboration based on EUROSTAT and CEPALSTAT for sample of selected countries

As regards poverty, in addition to a significant reduction over time, both per region and for the total number of countries, the coefficient of variation reflects a considerable increase and reproduction of inequalities; with Europe in this case presenting distinctively lower poverty rates, although with greater intra-region variation. For Latin America, on the contrary, the trend seems to have been remarkably positive, although with less internal variation, but with an increase in the inequalities between countries.

In this way, the results in welfare are as expected. At least the regional averages for the countries considered in each case present significant differences that persist over time. While the trends in the internal inequalities in each region do not provide as clear a behaviour as the interregional convergence. However, beyond the fact that these differences in the socioeconomic welfare appear to be structural, it is important to ask how unequal the countries making up both regions are in terms of income distribution and what their comparative behaviour in this social dimension has been in the twenty-first century.

In this respect, Fig. 9.1 confirms relatively well-known situations, both in terms of the structural differences that exist between the regions being studied, and in terms of the convergence process that has taken place in the last lustrums in distributive inequality measured by the Gini coefficient. While the data presented are average values, it is evident that the convergence process conceals a greater relative decline in the Gini coefficient of countries in Latin America. ${ }^{9}$ With a view to

\footnotetext{
${ }^{9}$ Recent literature analyses the possible reasons for the reduction in inequality, such as Azevedo et al. (2013), Lustig et al. (2016a), de la Torre et al. (2017) and Busso et al. (2017), among others. Despite this reduction in inequality, Latin American and the Caribbean continue to be some of the more unequal regions.
} 
Table 9.2 Gini Coefficient evolution within and between regions. Latin America ${ }^{\mathrm{a}}$ and Europe ${ }^{\mathrm{b}}$ (Years 2000-2017)

\begin{tabular}{l|c|c|c|c|c}
\hline Gini Coefficient & & & & & \\
Coefficient: 0-1 & $2000-2004$ & $2005-2008$ & $2009-2014$ & $2015-2017$ & Total 2000-2017 \\
\hline Europe (26) & 0.287 & 0.299 & 0.299 & 0.302 & 0.297 \\
\hline CV EU (26) & $14.7 \%$ & $14.6 \%$ & $12.3 \%$ & $13.6 \%$ & $12.7 \%$ \\
\hline Latin America (18) & 0.527 & 0.508 & 0.480 & 0.467 & 0.496 \\
\hline CV LA (18) & $10.2 \%$ & $9.0 \%$ & $9.8 \%$ & $10.5 \%$ & $9.4 \%$ \\
\hline Total EU + LA (44) & 0.392 & 0.387 & 0.373 & 0.370 & 0.378 \\
\hline CV Total (44) & $32.9 \%$ & $29.3 \%$ & $26.5 \%$ & $25.3 \%$ & $28.3 \%$ \\
\hline Gap LA/EU & 1.83 & 1.70 & 1.61 & 1.55 & 1.67 \\
\hline
\end{tabular}

Source: own elaboration based on World Bank, EUROSTAT and CEPALSTAT for sample of selected countries

${ }^{a}$ Gini coefficient of family per capita income calculated in the distribution of people

${ }^{\mathrm{b}}$ Gini coefficient of equivalent income (OECD scale for normalization of household size) calculated in the distribution of people

furthering this analysis, Table 9.2 examines how much the inequality or equality processes have converged or diverged in the countries from each region and between regions (measured using the coefficient of variation of the Gini of each country in each period).

In this regard, although these data confirm that observed in Fig. 9.1, the convergence process presents degrees of divergence. While in recent years the region of Latin America has registered a reduction process in the average inequality, the inequality between countries does not appear to have undergone considerable changes. On the contrary, in Europe, the slight increase in the Gini coefficient after the recession in 2009 occurred alongside a decline in the internal inequality between countries. As a whole, there is evidence in favour of convergence: a reduction both in the average Gini and in the coefficient of variation.

The evolution of the Gini coefficients in Latin America and in Europe illustrates the different institutional and distributive networks that characterise these countries. Statistical information reveals that in Europe coming through the "Great Recession" entailed a moderate increase in the Gini; while in Latin America, in the same period, the coefficient reduced. We can speculate that the validity of more robust institutions in Europe guarantees a certain distribution pattern, with some flexibility. This does not occur in Latin America, although what could happen is that a certain institutional configuration (in particular, in terms of pension cover and conditional cash transfers) has been reached with the commodities boom, explaining a certain level of convergence.

The income distribution in each country is the result of the complex interaction of innumerable economic, demographic, social and institutional factors. As was mentioned in the introduction, inequality in the income distribution between the population on a global level or in a region reflects the combined effect of inequality 
in countries and the inequality between countries. From this perspective, the simplified description of the behaviour of global inequality during the last one hundred years shows that first there was a period in which the inequality in countries reduced, but the gap between countries increased. More recently, and as can be observed in the data, the trend has changed - at least for countries in Latin America and Europe-: the inequality in the income distribution is tending to increase in some societies and to decrease in others, reducing the gap between the countries from each region and between the regions.

A problem widely explored by development literature is the relationship between welfare indicators and economic inequality. Based on the theory of social welfare, an improvement in the income of households or individuals could be considered as evidence that the functioning of the economy generated improved material living conditions for the country's population. Therefore, income could be used as a proxy measure of welfare. In turn, an improvement in the indicators of distribution, which can be measured using the Gini coefficient as a reduction of same, would indicate less inequality in consumption opportunities, bringing greater "profit" to individuals. ${ }^{10}$

In any case, considering the magnitude of the interregional differences, it is evident that Europe and Latin America present different development models, welfare regimes and social income. But while the topic is on the international agenda, the empirical evidence is not conclusive as regards the direction and the force taking place in these dimensions. In any case, a welfare and equity optimum is an expected development goal in the majority of societies in the world, although it is not very legitimate to deduce causality from these relations. ${ }^{11}$ In this context, it seems interesting to study the relation between inequality and the underlying socioeconomicinstitutional processes for the countries being studied.

In this regard, below, the average Gini coefficient is empirically related with economic development (GDP per capita) and social welfare (absolute poverty rate) indicators. If the relation between Gini and the GDP per capita is analysed, countries in Latin America have relatively higher Gini indices (greater inequality) and low GDP per capita. As regards the poverty rate, European countries (with lower

\footnotetext{
${ }^{10}$ In addition to the impact of inequality on growth and poverty, inequality has a direct and negative impact on social welfare. According to the psychological relative privation theory (Yitzhaki 1979), individuals and households do not assess their welfare levels only in absolute terms of consumption or income, but also in relative terms. Therefore, for any given income level in a country, and considering that individuals and households compare themselves, inequality has a negative effect on welfare. Income distribution measures, such as the Gini coefficient, are also being analysed because inequality in income before tax can lead to a high demand for redistributive policies (Romer 1975) and, therefore, higher social expenditure (Meltzer and Richard 1983; Shelton 2007).

${ }^{11}$ In statistical terms, the correlation between variables does not automatically mean that the change in one variable is the cause for change in the values of the other variable; in other words, that there is a causal relationship between the two events.
} 
Gini) are also less poor. Firstly, Tables 9.3, 9.4 and 9.5 below show the way in which these aspects are related as a whole for the countries making up the regions being studied.

Upon performing an in-depth analysis of the correlations of Gini with the abovementioned variables for all the countries considered, we find expected results: more unequal countries have greater poverty and a lower GDP per capita. In other words, a lower inequality per income, measured using the Gini, is positively correlated with the general socioeconomic welfare, at least for the average of the countries considered in this study during the 2000-2017 period.

However, a relevant fact is that this relation is not as pronounced when the analysis is segmented according to regions. In fact, upon recalculating the Pearson correlations for each region separately, the strength of the relation between the welfare variables and the Gini decreases considerably (Poverty-Gini and GDP-Gini), although it continues to be significant. This change reveals the existence of a third factor associated with the Gini, which must be associated with the politicaleconomic conditions of the national systems making up each region.

These differences in the correlations between regions can also be observed in the following Figs. 9.2, 9.3, and 9.4, in which for each of the abovementioned correlations, the point clouds describe the differences between regions. In this respect, while areas of superimposition can be observed, it is clear that there are two sets of countries, with dissimilar degrees of inequality associated with welfare between regions, and relatively similar degrees of inequality within each region.

\subsection{Relation Between Inequality and the Primary and Secondary Sources of Income Distribution}

This decline in the relation between welfare indicators and the Gini coefficient when analysed per region, regardless of the historical period being considered, again reveals the structural differences between the compared regions. This fact drives us to reflect on the underlying distributive processes associated with the performance of inequality. On the one hand, to examine the distributive role of social public expenditure as a percentage of the GDP and, on the other hand, the role of

Table 9.3 Pearson correlations for Latin America and Europe (Years 2000-2017)

\begin{tabular}{l|l|l|l}
\hline & Gini & Poverty & GDP pc \\
\hline Gini & 1 & & \\
\hline Poverty & $0.863 * * *$ & 1 & \\
\hline GDP pc & $-0.832 * * *$ & $-0.833 * * *$ & 1 \\
\hline
\end{tabular}

Note: significance of the effects $* p<0.05, * * p<0.01$, *** $p<0.001$

Source: own elaboration based on World Bank, EUROSTAT and CEPALSTAT for sample of selected countries 
Table 9.4 Pearson correlations for Latin American countries (Años 2000-2017)

\begin{tabular}{l|l|l|l}
\hline & Gini & Poverty & GDP pc \\
\hline Gini & 1 & & \\
\hline Poverty & $0.550 * * *$ & 1 & \\
\hline GDP pc & $-0.468 * * *$ & $-0.748 * * *$ & 1 \\
\hline
\end{tabular}

Note: significance of the effects: $* p<0.05, * * p<0.01, * * * p<0.001$

Source: own elaboration based on World Bank, EUROSTAT and CEPALSTAT for sample of selected countries

Table 9.5 Pearson correlations for European countries (Years 2000-2017)

\begin{tabular}{l|l|l|l}
\hline & Gini & Poverty & GDP pc \\
\hline Gini & 1 & & \\
\hline Poverty & $0.509 * * *$ & 1 & \\
\hline GDP pc & $-0.473 * * *$ & $-0.632 * * *$ & 1 \\
\hline
\end{tabular}

Note: significance of the effects: $* p<0.05$, ** $p<0.01$, *** $p<0.001$

Source: own elaboration based on World Bank, EUROSTAT and CEPALSTAT for sample of selected countries

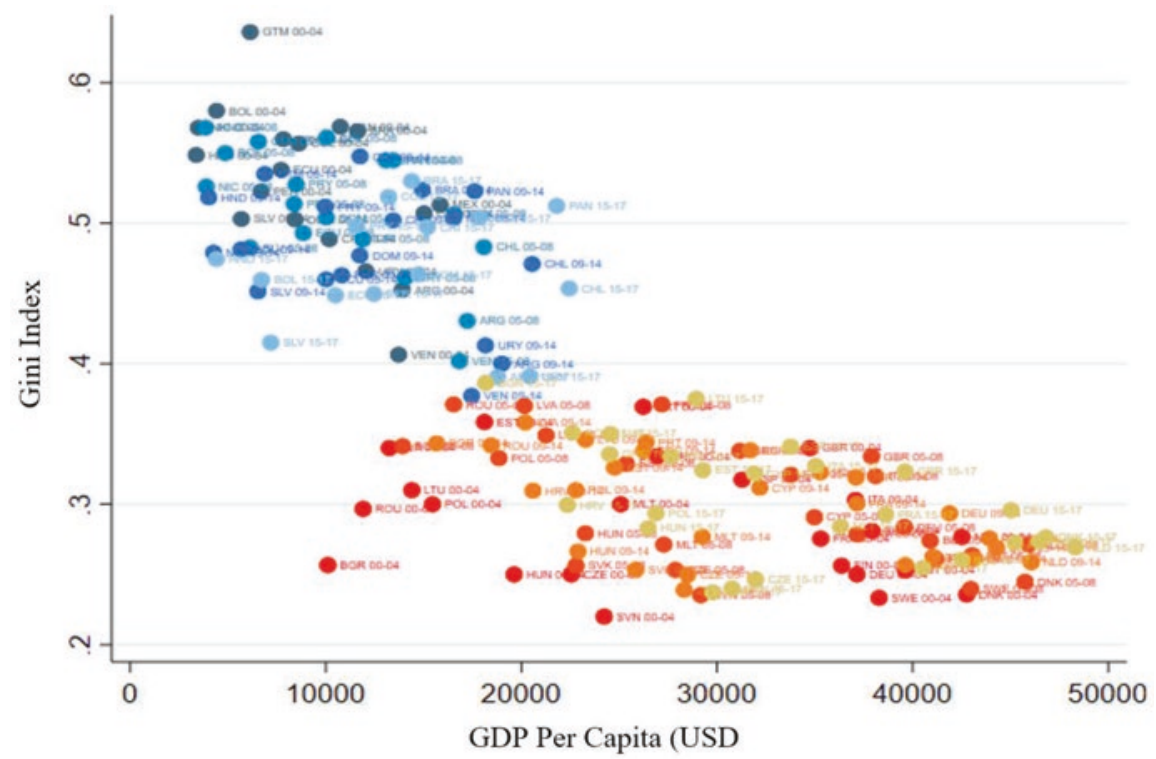

Latin American countries: Blue colour European countries: Red colour

Fig. 9.2 Gini Index and GDP per capita correlation. Latin American and European countries (Years 2000-2017). Source: own elaboration based on World Bank, EUROSTAT and CEPALSTAT for sample of selected countries 


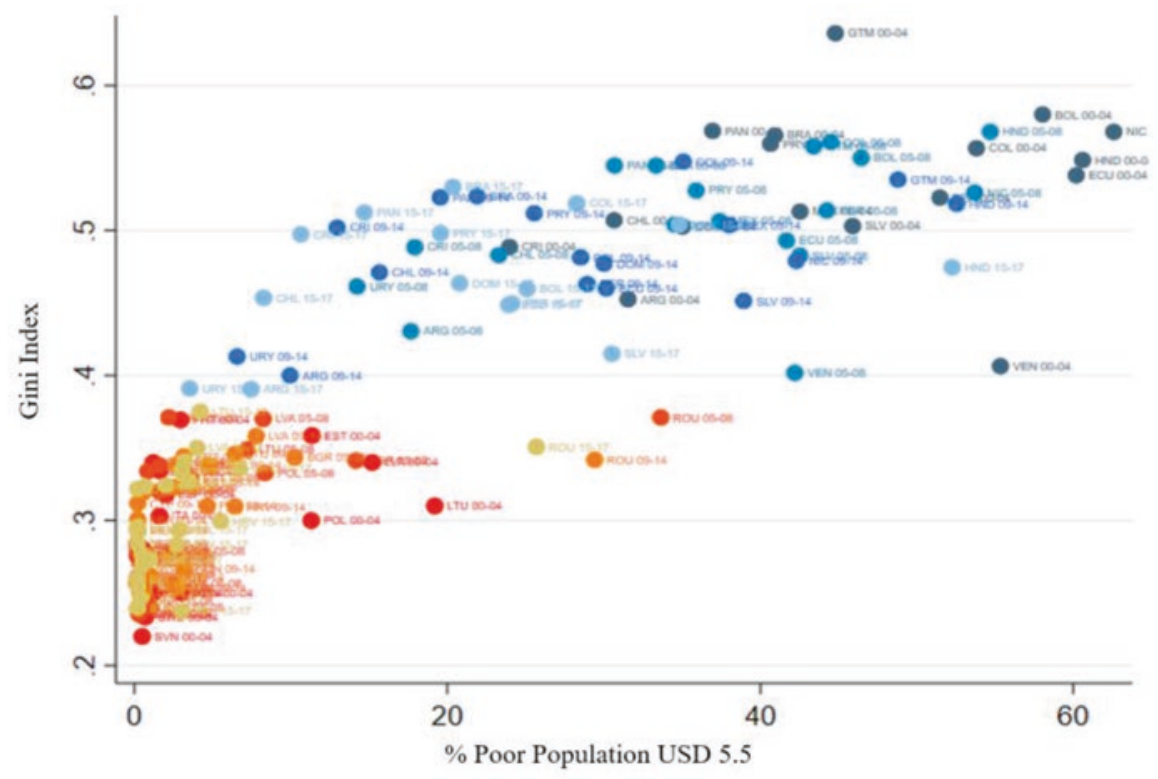

Latin American countries: Blue colour European countries: Red colour

Fig. 9.3 Gini Index and Absolute Poverty Rate correlation (USD 5.50 PPA daily). Latin American and European countries (Years 2000-2017). Source: own elaboration based on World Bank, EUROSTAT and CEPALSTAT for sample of selected countries

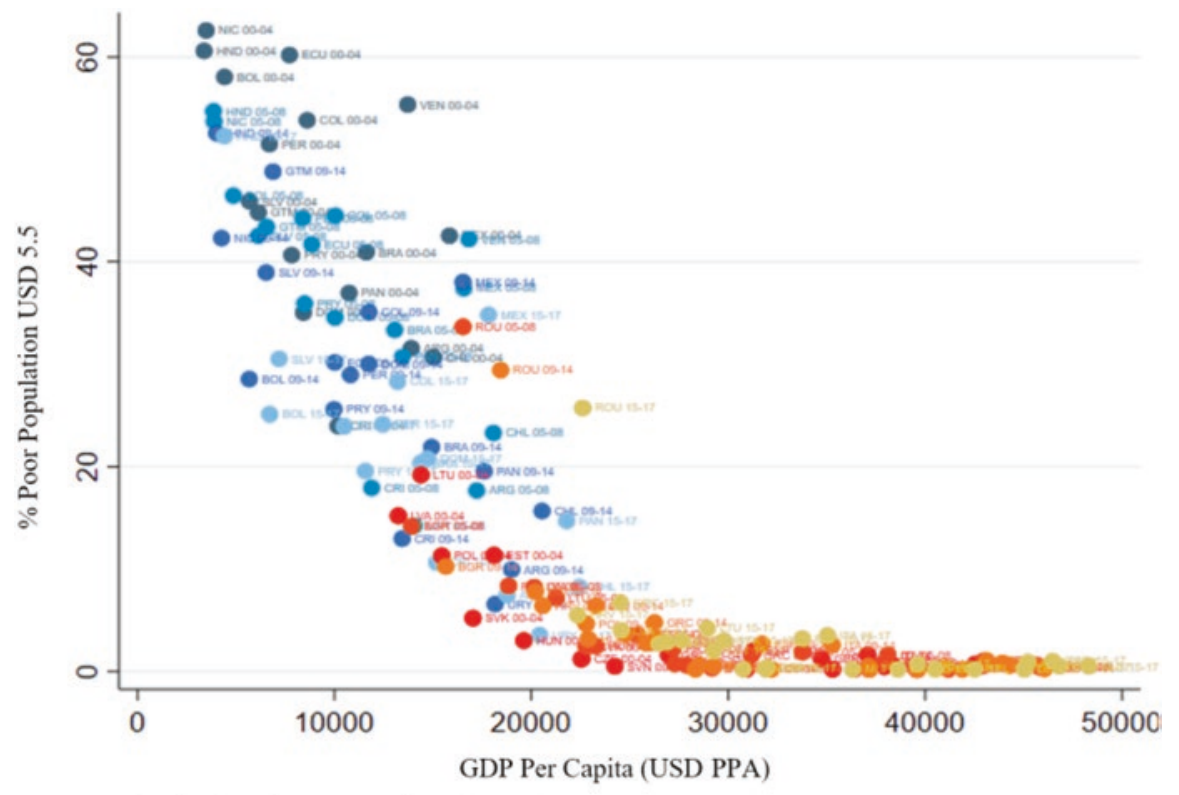

Latin American countries: Blue colour European countries: Red colour

Fig. 9.4 Correlation between Absolute Poverty Rate (USD 5.50 PPA daily) and per capita GDP. Latin American and European countries (Years 2000-2017). Source: own elaboration based on World Bank, EUROSTAT and CEPALSTAT for sample of selected countries 


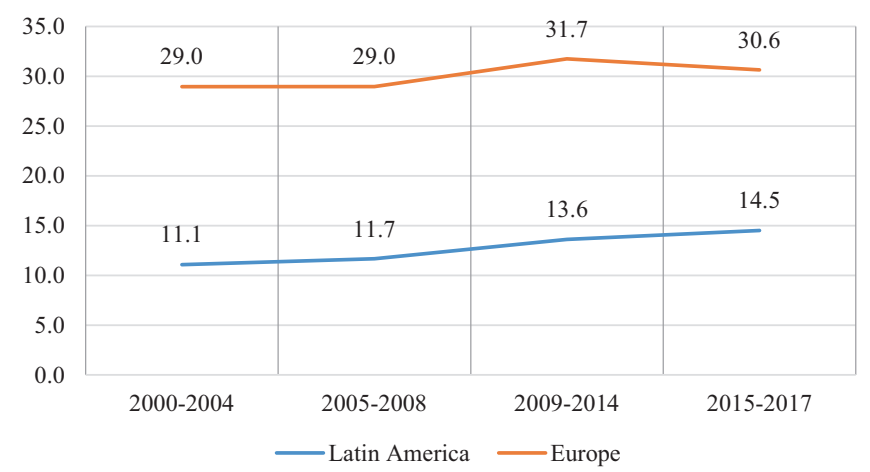

Fig. 9.5 Evolution of social public expenditure of different levels of government [Based on the OECD Classification of Government Functions (COFOG)]. Latin America and Europe (Years 2000-2017). As a percentage of GDP. Source: own elaboration based on EUROSTAT and CEPALSTAT

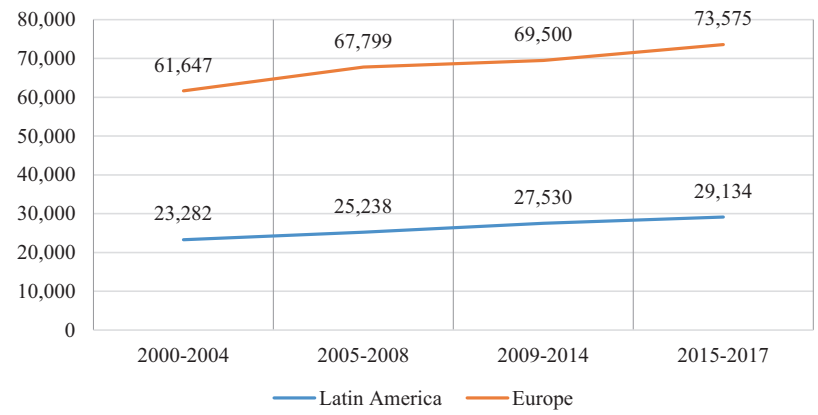

Fig. 9.6 Evolution of the average productivity per worker. Latin America and Europe (Years 2000-2017). In USD PPA 2011. Source: own elaboration based on World Bank

labour productivity as an annual average of the contribution of each worker to the added value in dollars (PPP). In this regard, the labour productivity can be interpreted as a proxy of the value of the salary/remuneration. ${ }^{12}$

The comparative evolution of both indicators is presented in Figs. 9.5 and 9.6. The graphs once again show the structural inequalities in the average of the countries from both regions. Although there is an upward trend for both social expenditure and average productivity, and unlike the inequality in the Gini index, the gaps continue over time, without showing any convergence. In other words, the increases in productivity in Europe did not result in better welfare or greater equality; on the

\footnotetext{
${ }^{12}$ The labour productivity variable used here shows the total volume of production (GDP) produced by one labour unit (number of persons employed) during a specific time period. This indicator of productive capacities provides general information about the efficiency and quality of the capital - both physical and human — in the productive process for a given economic and social context. See: http://www.ilo.org/ilostat-files/Documents/description_PRODY_SP.pdf
} 
Table 9.6 Pearson correlations for Latin America and Europe (Years 2000-2017)

\begin{tabular}{l|l|l|l}
\hline & Gini & Productivity & Social spending \\
\hline Gini & 1 & & \\
\hline Productivity & $-0.811 * * *$ & 1 & \\
\hline Social spending & $-0.827 * * *$ & $0.842 * * *$ & 1 \\
\hline
\end{tabular}

Note: significance of the effects: $* p<0.05, * * p<0.01$, *** $p<0.001$

Source: own elaboration based on World Bank, EUROSTAT and CEPALSTAT for sample of selected countries

Table 9.7 Pearson correlations for Latin American countries. Years 2000-2017

\begin{tabular}{l|l|l|l}
\hline & Gini & Productivity & Social spending \\
\hline Gini & 1 & & \\
\hline Productivity & $-0.475^{* * *}$ & 1 & \\
\hline Social spending & -0.192 & $0.344 * *$ & 1 \\
\hline
\end{tabular}

Note: significance of the effects: $* p<0.05, * * p<0.01, * * * p<0.001$

Source: own elaboration based on World Bank, EUROSTAT and CEPALSTAT for sample of selected countries

Table 9.8 Pearson correlations for European countries (Years 2000-2017)

\begin{tabular}{l|l|l|l}
\hline & Gini & Productivity & Social spending \\
\hline Gini & 1 & & \\
\hline Productivity & $-0.402 * * *$ & 1 & \\
\hline Social spending & $-0.517 * * *$ & $0.756 * * *$ & 1 \\
\hline
\end{tabular}

Note: significance of the effects: $* p<0.05, * * p<0.01, * * * p<0.001$

Source: own elaboration based on World Bank, EUROSTAT and CEPALSTAT for sample of selected countries

contrary, there was a moderate relative loss in social welfare. During the last period a decline was recorded in the participation of social expenditure. On the contrary, Latin America registered a constant increase both of productivity and social expenditure, which would have a positive effect both on welfare and equity.

Likewise, although the differences between regions persist, the behaviour of both indicators shows certain divergences. In particular, social public expenditure grew by $31 \%$ in Latin America, while in Europe it grew by 5\%. As regards the average productivity, the growth was also higher in Latin America (25\% compared to 19\% in Europe). In other words, for Europe, the improvement in productivity was not accompanied by an increase of the same magnitude, or similar, in social expenditure. In this regard, the dynamic observed in the 2000-2017 period is consistent with the previous hypothesis about the institutional rigidity that reinsures certain inequality patterns. In this context, it is important to reflect on the direction and strength of the correlation existing on a national level between the percentage of social expenditure in GDP and the labour productivity in dollars (PPP 2011) in Tables 9.6, 9.7, and 9.8. 
Table 9.9 Partial correlations for Latin American and European countries, controlling by region (Years 2000-2017)

\begin{tabular}{l|l|l|l}
\hline & Gini & Productivity & Social spending \\
\hline Gini & 1 & & \\
\hline Productivity & $-0.399 * * *$ & 1 & \\
\hline Social spending & $-0.342 * * *$ & $0.572 * * *$ & 1 \\
\hline
\end{tabular}

Note: significance of the effects: $* p<0.05, * * p<0.01$, $* * * p<0.001$

Source: own elaboration based on World Bank, EUROSTAT and CEPALSTAT for sample of selected countries

A distinctive trait of the European continent is that a significant (and positive) relationship can be observed between social expenditure and Gini. Therefore, the higher the social expenditure, the lower the inequality in Europe, while in Latin America this relationship dissolves and is not significant. In all cases, whether aggregate or broken down into regions, the relationship between social expenditure and average productivity is positive and significant, although this relationship is more pronounced in Europe than in Latin America.

An analysis of partial correlations (Table 9.9) regarding these same variables, when controlling for region, confirms the results. ${ }^{13}$ Based on this methodology, the negative relations between the Gini coefficient and labour productivity and social expenditure are maintained. The relations between the last two variables, productivity per worker and social expenditure, is positive; strengthening the hypothesis that an increase in average productivity affects countries' capacity to generate surpluses devoted to social expenditure. It is important to observe that, when controlling per region, the correlation is less in terms of magnitude than when taking the total sample of countries (Figs. 9.7, 9.8, and 9.9).

\subsection{Factorial and Temporal Breakdown of Inequality}

The main theory of this work is that, in socioeconomic contexts with different degrees of economic development, primary income distribution is a key factor to explain both welfare levels and income distribution, even in the presence of robust social security systems responsible for guaranteeing a minimum basic income (ILO 2012, 2013, 2014). Although these systems can have a considerable redistributive impact, this depends on their degree of maturity (sustainability), coverage and transfer capacity, which is ultimately also a function of the productive development and the primary income distribution of each country (Moreno 2012, 2015). In any case, it is important to accept that there are important structural and institutional

\footnotetext{
${ }^{13}$ Instead of calculating the correlations separately, one correlation is calculated for each pair of variables, controlling for a possible "continental effect".
} 


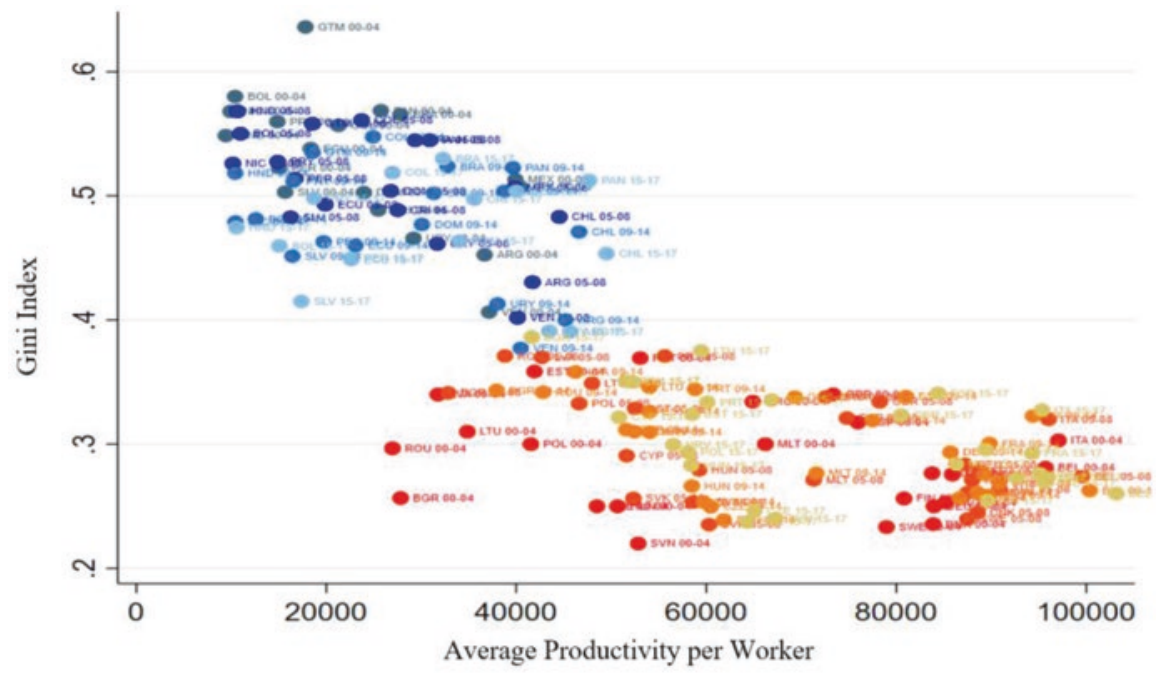

Latin American countries: Blue colour European countries: Red colour

Fig. 9.7 Gini Index and Average Productivity per Worker correlation. Latin American and European countries (Years 2000-2017). Source: own elaboration based on World Bank, EUROSTAT and CEPALSTAT for sample of selected countries

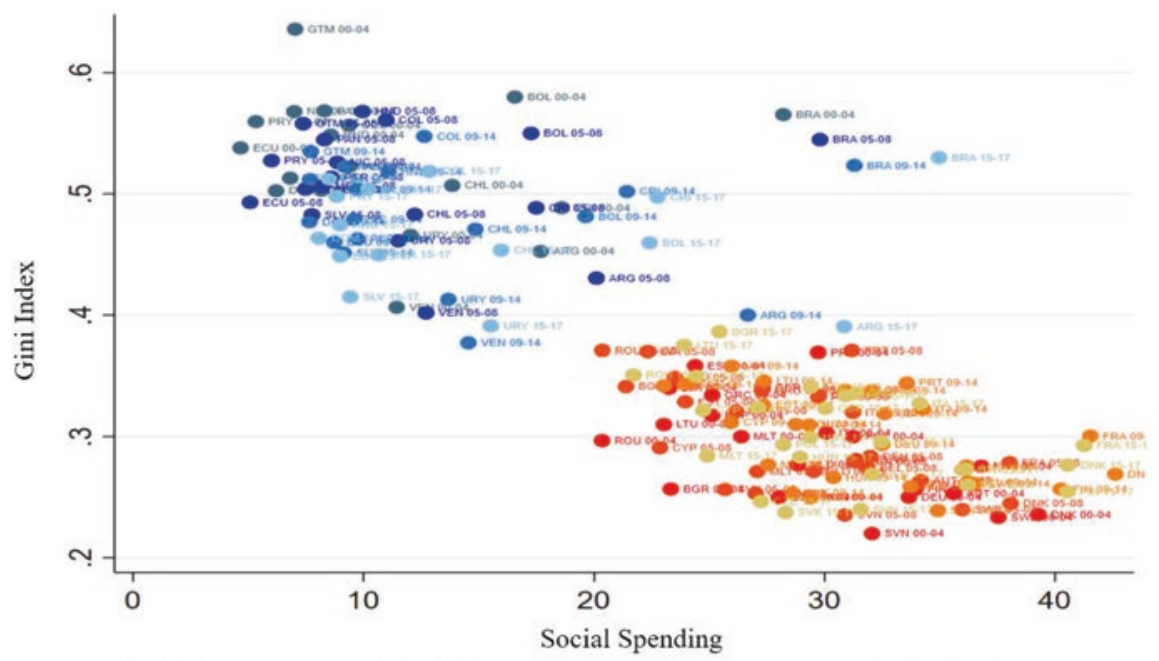

Latin American countries: Blue colour European countries: Red colour

Fig. 9.8 Gini Index and Social Spending correlation. Latin American and European countries (Years 2000-2017). Source: own elaboration based on World Bank, EUROSTAT and CEPALSTAT for sample of selected countries

heterogeneities between the countries from both regions, both in productive material and in social welfare systems. Nevertheless, both the backgrounds and the evidence gathered to date show that the regions have their own political-institutional weight, in other words, the differences between regions prevail over the differences between countries from one same region. 


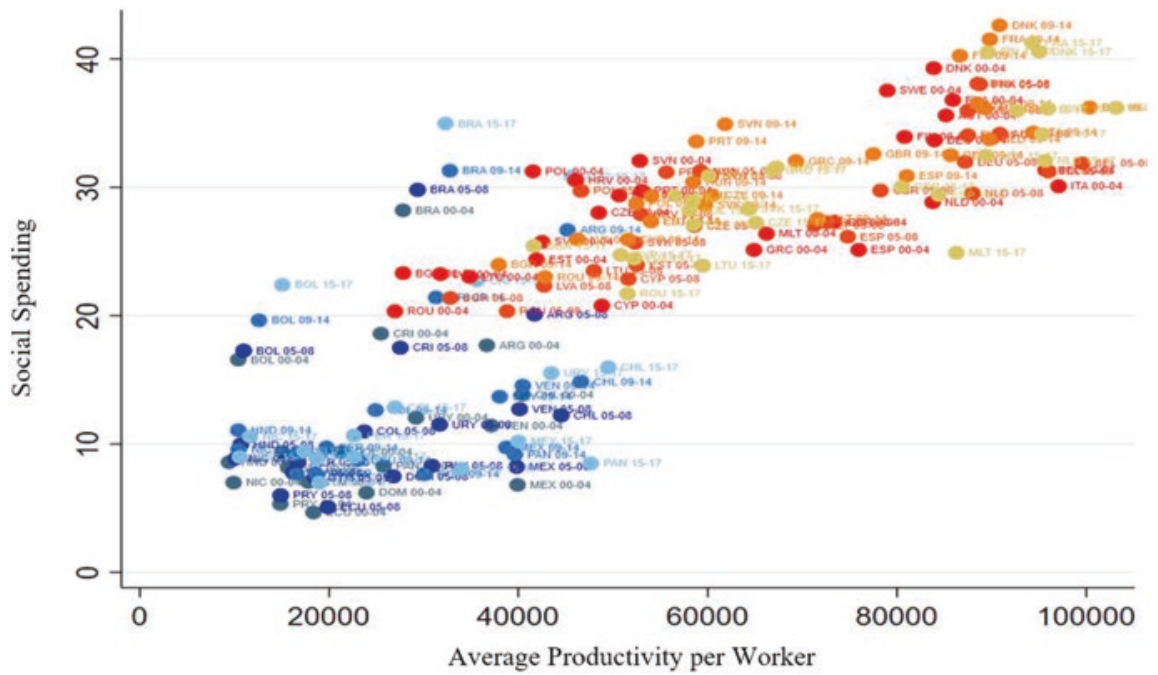

Latin American countries: Blue colour European countries: Red colour

Fig. 9.9 Social Expenditure and Average Productivity per Worker. Latin American and European countries (Years 2000-2017). Source: own elaboration based on World Bank, EUROSTAT and CEPALSTAT for sample of selected countries

With a view to examining this theory on a comparative level, using the data available for the countries from Europe and Latin American analysed in the previous sections, a factorial model is adjusted with the three variables considered in the previous section: (1) inequality in income distribution (Gini index), (2) labour productivity (added value per worker), and (3) social expenditure (\% of the social expenditure in the total national GDP). As has been done thus far, the analysis units are the periods-nations corresponding to 44 countries, 26 from Europe and 18 from Latin America, with the years being grouped into four time periods: 2000-2004, 2005-2008, 2009-2014 and 2015-2017.

To summarise and structure the totality of this information a factorial analysis of principal components was applied in order to obtain the most important patterns of differentiation of the countries-periods. This procedure helped to identify two underlying factors dominating the processes of economic (in)equality between the regions being examined. Both components, associated with inequality, but in inverse ways, explain almost $95 \%$ of the total variance. On the one hand, the vector "development with equity" (horizontal axis) organises the countries according to their level of economic development and its implications on inequality: countries situated more to the right are simultaneously more developed and egalitarian; while those situated more to the left are less developed and more unequal. On the other hand, the vector "secondary redistribution-inequity" (vertical axis) organises the countries according to the compensatory efficiency of their social expenditure on inequality: the countries situated lower down have a more efficient relationship between social expenditure and equity than those higher up, for which higher social expenditure does not help to reduce inequality. 


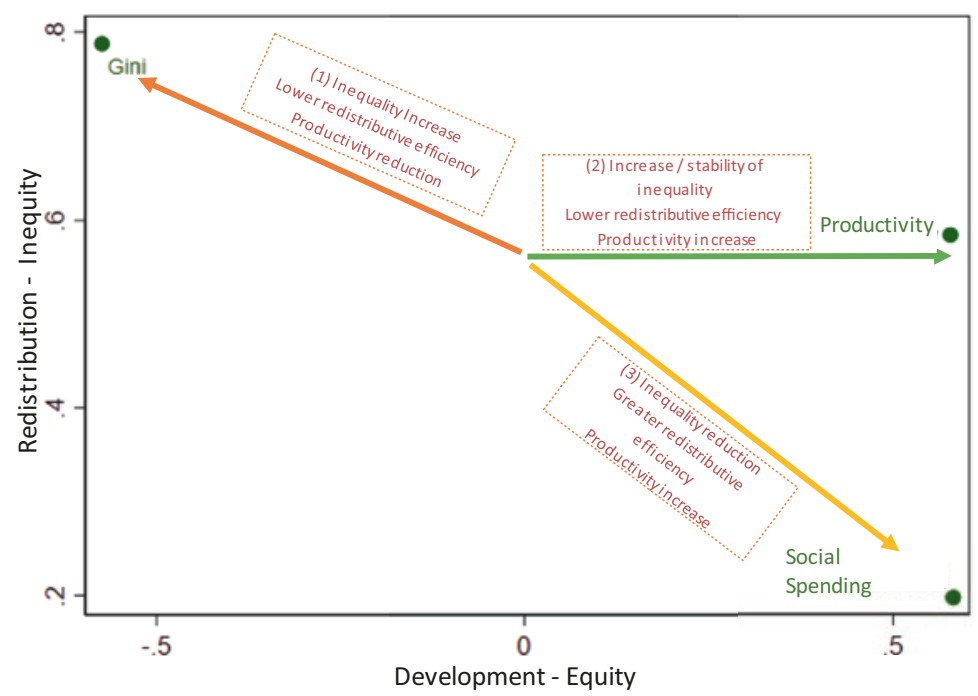

Fig. 9.10 Principal component analysis: Identified components and types of trajectories for countries in Latin America and Europe (Years 2000-2017). Source: own elaboration based on World Bank, EUROSTAT and CEPALSTAT for sample of selected countries

By relating both factors, different "national inequality regimes" (Boyer 2014) can be identified, both in Europe and in Latin America, and their main movements over time can be described. In fact, following this theoretical-methodological model, the factorial position of the variables considered can be classified, as well as that of the countries-periods considered in the analysis.

Figure 9.10 shows the position in the factorial space of the variables considered, helping to identify different possible trajectory types. In particular, three main types can be observed: (1) reduction in inequality due to a greater redistributive efficiency of the social expenditure and a distributive improvement in the primary income resulting from an increase in labour productivity; (2) stability or increase in inequality with an increase in productivity but with a loss in the redistributive efficiency of the social expenditure; (3) increase in inequality as a result of the worsening of the primary distribution due to a decline in labour productivity, as well as an inefficient increase in social expenditure. Naturally, the slope of the trajectory will depend on the relative importance of the processes identified.

In turn, Fig. 9.11 distributes the countries-periods around the identified axes and helps to examine, firstly, how the cases are distributed across the quadrants demarcated by the mentioned axes; and, secondly, what trajectory the countries followed for the periods considered. The axes describe four situations or types: (1) the upper left quadrant brings together countries with low economic development, high inequity and low redistributive efficiency of the social expenditure; (2) the lower right quadrant, countries with high economic development, low inequality and redistributive efficiency of the social expenditure; (3) the lower left quadrant, countries with low economic development, high inequality and compensatory redistributive 


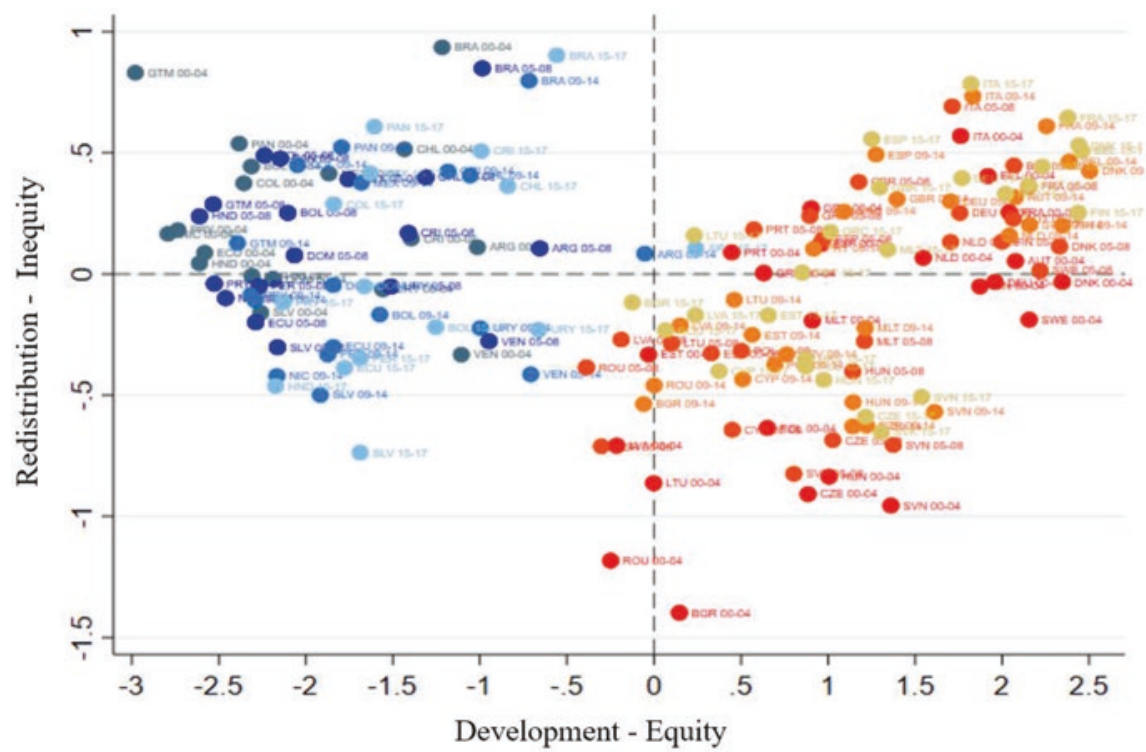

Latin American countries: Blue colour European countries: Red colour

Fig. 9.11 Principal Component Analysis: Scores for Latin American and European countries (Years 2000-2017). Sources: Own elaboration, Gini Index: own elaboration based on EUROSTAT and CEPALSTAT, Average productivity per worker: own elaboration based on ILOSTAT and World Bank, Social public expenditure of different levels of government: own elaboration based on EUROSTAT, CEPALSTAT and National statistics

efficiency through social expenditure; and (4) the upper right quadrant, countries with high economic development, moderate inequality and less redistributive efficiency through social expenditure.

Based on this matrix, it is easy to observe that, regardless of the possible movements that took place during the 2000-2017 period, while the countries-periods of Latin America are essentially concentrated in the left quadrants (lower development with greater distributive inequity), European countries are mainly located in the right quadrants (greater development with lower distributive inequity). Likewise, the countries-periods from both regions are divided relatively clearly between the upper and lower quadrants of the graph according to the effectiveness of social expenditure as a factor associated with lower or higher inequality (greater relative inequality with higher social expenditure compared to lower relative inequality with lower social expenditure). This classification includes a series of European countries-periods that are notable for their lower degree of relative development but high compensatory efficiency through social expenditure (Bulgaria, Romania, Lithuania), which however seem to move upwards. At the other extreme, there is a notable presence of a series of Latin American countries-periods-essentially Brazil-with greater relative productive development, but with a high social expenditure that is considerably inefficient at reducing inequality. In this case, there is a slight positive movement towards greater development with equity. 
Precisely, in terms of trajectories, as it is a factorial space, it is more relevant to examine the direction of the trajectories than the distances travelled, even when these can provide additional information. Furthermore, as can be observed, although countries in Latin America and Europe took three dissimilar five-year-long trajectories, which explains the distributive convergence observed in Table 9.3, these were not sufficient to alter their structural distribution in the previously identified quadrants.

A first intuitive examination of the trajectories confirms that, beyond particular situations, the majority of the European countries registered a type (2) trajectory (Graph 10): increase or stability (depending on the slope) of inequality, with an increase in productivity and lower redistributive efficiency of social expenditure. In this respect, we can speculate that the effects of the Great European Recession and the type of recovery that took place left a specific mark on distributive inequity. Simultaneously, the austerity policies implemented resulted in the loss of the redistributive efficiency of social expenditure; a historical process that fits quite well with what is known as the "Bronze Age" of the European welfare regime (Moreno 2015, 2016).

On the contrary, Latin American countries followed a different trajectory. This trajectory corresponds with type (1) (Fig. 9.10): reduction of inequality with an increase in productivity and greater redistributive efficiency of social expenditure. Once again, the slope of the trajectory provides an idea of the achievements in terms of reducing inequality. The growth model aimed at the internal and expansive social policies market (often, linked with old age pension benefits and conditional cash transfers), during the boom of the prices of commodities, would explain the type of trajectory observed (CEPAL 2014).

Based on the results obtained with this analysis model, in addition to confirming that intra-regional inequalities continue to prevail, the weak convergence process that took place in income distribution during the first three lustrums of the twentyfirst century can be understood in terms of the particular primary income distribution and secondary income distribution processes that took place almost unanimously in the countries from each region. This can be observed in the distribution of the countries-periods in the factorial axes according to the region to which they belong. In other words, the expanded analysis reveals that the convergent trends in inequality are the result of a series of divergent processes linked to productive development and the different models of social policy implemented.

\subsection{Conclusions}

During the last quarter of the twentieth century and the current twenty-first century, both Europe and Latin America have undergone profound transformations in their social welfare and income distribution structures in the context of the changes that have taken place as a result of international political-economic conditions (globalisation), with different scope and impact depending on the way in which each society 
absorbed, regulated and processed said trends. The current global context represents a period of exhaustion, transition and redefinition of these processes. The impact of these changes on the social reproduction patterns of economic inequalities, both in direction and in magnitude, has not been sufficiently explored by social science literature. While there are studies of national cases, and, even, analyses based on comparisons between countries from one same region, analyses comparing the degrees of inequality of both regions are particularly scarce.

In this context, a comparative analysis of countries from Europe and Latin America is conducted to assess changes in economic inequality during the first lustrums of the twenty-first century. This study initially examines how equal-unequal the national-regional systems taken as case studies are in terms of their degree of socioeconomic-productive development, economic inequalities and their effects on poverty. Secondly, assuming the presence of unequal degrees of welfare-inequity between regions-countries, how can these different levels of welfare, economic inequality and social development between Latin America and Europe be explained? What are the main distributive processes explaining the changes that have taken place in recent decades?

To answer the first question, we described the inequality in the distribution of national income between and in the regions considered, as well as their recent changes over time, based on a model linking the Gini coefficients of each country, in four different stages from the 2000-2017 period, with the productive capacities of each economy (primary income distribution) and the redistributive efforts made by the governments through social expenditure (secondary income distribution). Based on this model, and following a comparative analysis between countriesperiods for Europe and Latin America, we sought to determine a structuring descriptive pattern of the different ways in which both regions and the national systems manage the distributive inequalities, as well as their movements over time during the study period.

With this framework, firstly, the relationship between inequality and welfare was explored, analysing the differences between regions. Upon controlling for region, the decline in the relation between the welfare indicators and the Gini coefficient of the countries provides evidence of the structural differences between regions, beyond the correlations and differences assumed to be present on an intra-regional level. In accordance with the available evidence, in the last two decades of the twenty-first century, Europe and Latin America have reduced their economic inequality gaps, but while the distributive inequality has reduced in the majority of Latin American countries, an inverse process, although moderate, and varying depending on the country, was happening in the majority of countries in Europe. Although there were exceptions to both trends, as well as different national behaviours within each region, the analysed evidence confirms these processes, revealing the factors underlying these behaviours. In both cases, although with similar trends, intra-regional inequality appears to have increased.

The decline observed in the correlation between GDP per capita and Gini index in both regions drove the analysis of the role played by two factors more directly associated with the behaviour of inequality: the distributive role of social 
expenditure as a percentage of the GDP, and the average labour productivity. The analysis of the relation between social expenditure and Gini shows that, the higher the social expenditure, the lower the inequality in Europe; while in Latin America this relationship dissolves and is not significant. The relation between productivity and social expenditure is positive and significant, in both cases, although this relation is more pronounced in Europe than in Latin America.

The model applied was used to analyse how the productive development capacities and the levels of secondary income distribution covered by the state intervene in the social reproduction of inequalities, in different ways across the continents.

As regards the second topic proposed, a particularly relevant goal was to assess how and in what way the different paths taken, beyond the results attained, can be explained by more structural factors affecting each region-country: the productivity of the capital-work relation (in terms of structural heterogeneity, institutional regulation models and ways in which these factors segment the labour demand), and the weight of social expenditure in the gross domestic product (as an expression of the level of coverage and redistribution of income provided by social policies).

In response to this second goal, a factorial-qualifying analysis was conducted of the different economic inequality systems that characterise each national system. Considering a series of indicators regarding average labour productivity, the level of social expenditure and its effects on welfare for each country, we managed to demonstrate a conceptual bridge that explains the distributive inequality of the income between both regions. ${ }^{14}$ Assuming the presence of unequal degrees of welfareinequity between the regions being studied, the analysis showed the main processes of the changes that took place in economic inequality in recent decades in the countries making up both systems.

Based on the three variables considered (Gini coefficient, labour productivity and social expenditure), two specific components were identified for the analysis: "Redistribution and Inequity" and "Development and Equity". In general, countries from Latin America developed around the axis "Development and Equity", with certain levels of redistribution. While Europe, located in the position DevelopmentEquity, made movements in the period analysed around the axis "Redistribution and Inequity". Some saw their social rights diminish while others saw them improve. Lastly, although this work provides evidence about the reduction in economic inequality between the regions, it also reveals the existence of structural factors that would explain intra-regional distributive inequalities that continue to be important. Beyond the changes that have taken place in each region during the twenty-first century, the inter-regional dynamics are not convergent in terms of productive development and equity and efficiency of social expenditure.

\footnotetext{
${ }^{14}$ The analysis of these matters, from a perspective of the factors associated with income distribution, leads us to consider a methodological strategy of comparative analysis between countries, which opens up the possibility of developing theoretical formulations that transcend the borders of a society (Holt and Turner 1970). These analyses provide relevant conclusions to progress in this line of research in international comparison.
} 
Although the changes that took place within each region during the twenty-first century reduced the differences between the two continents, the interregional dynamics in terms of productive development and efficiency of social spendingkey to their relationship in both cases with the inequality in the distribution of social revenue - they moved in a divergent sense.

Acknowledgements The author greatly appreciates the contributions made to this chapter by Dr. José Saturnino Martínez García, Principal Investigator with INCASI for the La Laguna University. Likewise, he would also like to highlight the collaboration of Dr. Santiago Poy Piñeiro and Guido Gabriel Lamarmora M.A., both researchers with the Argentina Social Debt Observatory -UCA, who compiled the information presented in this study.

\section{References}

Adler, M., \& Schmid, K. (2012). Factor shares and income inequality: Empirical evidence from Germany 2002-2008. SOEPpaper, 460.

Alvaredo, F., Piketty, T., Chancel, L., Saez, E., Zucman, G., Perrotini, I., \& Muller, N. (2018). Informe sobre la desigualdad global 2018. World Inequality Lab. Retrieved from https:// wir2018.wid.world/files/download/wir2018-summary-spanish.pdf

Atkinson, A. B. (1975). The economics of inequality. Oxford: Oxford University Press.

Atkinson, A. B. (2009). Factor shares: the principal problem of political economy? Oxford Review of Economic Policy, 25(1).

Atkinson, A. B. (2015). Inequality: What can be done? Cambrigde: Harvard University Press.

Atkinson, A. B. (2016). Desigualdad: ¿Qué podemos hacer? Mexico: Fondo de Cultura Económica.

Atkinson, A. B., Piketty, T., \& Saez, E. (2011). Top incomes in the long run of history. Journal of Economic Literature, 49(1), 3-71.

Azevedo, J. P., Inchauste, G., \& Sanfelice, V. (2013). Decomposing the recent inequality decline in Latin America. Policy Research Working Paper, 6715. Washington, DC: World Bank.

Barba Solano, C. (2007). América Latina: regímenes de bienestar en transición durante los años noventa. Caderno CRH, 20(50), 197-211.

Barba Solano, C., \& Cohen, N. (2011). Perspectivas críticas sobre la cohesión social. Buenos Aires: CLACSO.

Bárcena, A., \& Prado, A. (2016). El imperativo de la igualdad. Por un desarrollo sostenible en América Latina y el Caribe. Buenos Aires: Siglo XXI y CEPAL.

Barrientos, A., \& Hulme, D. (2008). Social protection for the poor and poorest: An introduction. In Social protection for the poor and poorest (pp. 3-24). London: Palgrave Macmillan.

Boyer, R. (2014). Is more equality possible in Latin America?: A challenge in a World of contrasted but interdependent inequality regimes. Berlin: desiguALdades.net International Research Network on Interdependent Inequalities in Latin America.

Busso, M., Cristia, J. P., Hincapié, D., Messina, J., \& Ripani, L. (Eds.). (2017). Learning better: Public policy for skills development. Washington, DC: Inter-American Development Bank.

CEPAL. (2014). Pactos Para la igualdad. Hacia un futuro sostenible. Santiago de Chile: Naciones Unidas.

Daudey, E., \& García-Peñalosa, C. (2007). The personal and the factor distributions of income in a cross- section of countries. The Journal of Development Studies, 43(2), 812-829.

De la Torre, A., Messina, J., \& Silva, J. (2017). The inequality story in Latin America and the Caribbean: Searching for an explanation. In L. Bértola \& J. Williamson (Eds.), Has Latin American inequality changed direction? Looking over the long run. Springer Nature: Cham. 
Del Pino, E., \& Gago, A. (2017, February). Las reformas del bienestar en Europa y su impacto: un análisis del papel de la Unión Europea, los Nuevos Riesgos Sociales y las peculiaridades nacionales en el contexto de la Gran Recesión. Working document, Instituto de Políticas y Bienes Públicos (IPP) CSIC.

Del Pino, E., \& Rubio, J. (2016). Los Estados del Bienestar en la encrucijada. Madrid: Tecnos.

Dollar, D. (2005). Globalization, poverty, and inequality since 1980. Oxford University Press on behalf of the World Bank: World Bank. Retrieved from https://openknowledge.worldbank.org/ handle/10986/16430

Glyn, A. (2009). Functional distribution and inequality. Oxford: Oxford University Press.

Guillén, A. M., Luque, D., \& González, S. (2016). El Modelo social Europeo: evolución y retos. In E. Del Pino \& M. J. Rubio-Lara (Eds.), Los Estados del Bienestar en la encrucijada. Políticas sociales en perspectiva comparada. Madrid: Tecnos.

Hacker, J. S. (2011). Restoring retirement security: The market crisis, the 'Great Risk Shift,' and the challenge for our nation. Elder Law Journal, 19(1).

Holt, R. T., \& Turner, J. E. (Eds.). (1970). The methodology of comparative research: a symposium from the Center for Comparative Studies in Technological Development and Social Change and the Department of Political Science, University of Minnesota. New York: Free Press.

ILO. (2011). Piso de protección social para una globalización equitativa e inclusiva. Report of the advisory group on the "Piso de Protección social". Geneva: Oficina Internacional del Trabajo. Retrieved from https://www.ilo.org/wcmsp5/groups/public/@dgreports/@dcomm/@publ/documents/publication/wcms_176521.pdf.

ILO. (2012). Wage-led or profit-led supply: Wages, productivity and investment. Working Paper for Conditions of Work and Employment Series, 36. Geneva: International Labour Organization.

ILO. (2013, December). El Reto de la Desigualdad: Es Hora de Cambiar. Report presented for the Simposio sobre la Desigualdad de los ingresos, las instituciones del mercado de trabajo y el poder de los trabajadores. Geneva: ILO. Retrieved from https://www.ilo.org/wcmsp5/groups/ public/---ed_dialogue/---actrav/documents/meetingdocument/wcms 231211.pdf

ILO. (2014). Wage-led growth: An equitable strategy for economic recovery. Geneva: International Labour Organization.

Keeley, B. (2015). Income inequality: The gap between rich and poor. Paris: OECD.

Keeley, B. (2018). Desigualdad de ingresos: La brecha entre ricos y pobres, Esenciales OCDE. París: OECD Publishing. Doi: doi:https://doi.org/10.1787/9789264300521-es.

Krugman, P., Wells, R., \& Olney, K. (2008). Fundamentos de Economía. Barcelona: Reverté.

Kuznets, S. (1934). National income, 1929-1932. National Bureau of Economic Research, 39.

Lustig, N., López-Calva, L. F., \& Ortiz-Juárez, E. (2016a). Deconstructing the decline in inequality in Latin America. In K. Basu \& J. E. Stiglitz (Eds.), Inequality and growth: Patterns and policy: Volume II: Regions and regularities. Houndmills, Basingstoke, UK: Palgrave Macmillan.

Lustig, N., Lopez-Calva, L. F., Ortiz-Juarez, E., \& Monga, C. (2016b). Deconstructing the decline in inequality in Latin America. In Inequality and growth: Patterns and policy (pp. 212-247). London: Palgrave Macmillan.

Meltzer, A. H., \& Richard, S. F. (1983). Tests of a rational theory of the size of government. Public Choice, 41(3), 403-418.

Molero Simarro, R. (2013). Distribución primaria, crecimiento económico e ingresos de los más ricos: las causas subyacentes de la desigualdad de la renta en la economía mundial. Presented at the XV Reunión de Economía mundial: La riqueza cambiante en la economía mundial. Universidad de Cantabria, Santander, Spain.

Moreno, L. (2012). La Europa asocial. Crisis y Estado del Bienestar. Barcelona: Península.

Moreno, L. (2015). La Europeización del bienestar social en España. In C. Torres Albero (Ed.), España 2015. Situación social (1031-1041). Madrid: Centro de Investigaciones Sociológicas.

Moreno, L. (2016). Post-crisis and the bronze age of welfare in Europe. In S. Segado \& A. López (Eds.), The ailing welfare state. Madrid: Thomson Reuters Aranzadi. 
Moreno, L., \& Palier, B. (2005). The Europeanization of welfare: Paradigm shifts and social policy reforms. In P. Taylor-Gooby (Ed.), Ideas and welfare state reform in Western Europe (pp. 145-175). New York: Palgrave Macmillan.

OECD. (2013). Perspectivas Económicas de América Latina y el Caribe 2014. Logistica y Competividad Para el Desarrollo. Paris: OECD Publishing. Retrieved from http://latinports. org/perspectivas-economicas-deamerica-latina-2014.

Ostry, J. D., \& Berg, A. (2011). Inequality and unsustainable growth; Two sides of the same coin? (No. 11/08). International Monetary Fund.

Piketty, T. (2014). El capital en el siglo XXI. Madrid: Fondo de cultura económica.

Piketty, T. (2015). About capital in the twenty-first century. American Economic Review, 105(5), 48-53.

Romer, T. (1975). Individual welfare, majority voting, and the properties of a linear income tax. Journal of Public Economics, 4(2), 163-185.

Salvia, A. (2015). Heterogeneidad estructural, desigualdad económica y globalización en América Latina. En Hernández Gómez, E. y Ramírez Urquidy, M. Bienestar y Pobreza en América Latina: Una visión desde la frontera norte de México. Universidad Autónoma de Baja California: México. pp.11-54.

Shelton, C. A. (2007). The size and composition of government expenditure. Journal of Public Economics, 91(11-12), 2230-2260.

Stiglitz, J. E. (2000). Capital market liberalization, economic growth, and instability. World Development, Elsevier, 28(6), 1075-1086.

Therborn, G. (2013). Las clases en el siglo XXI. New Left Review, 78, 11-38.

UN. (2015). Transformar nuestro mundo: Agenda 2030 para el desarrollo sostenible. Resolution 70/1 of the General Assembly of the United Nations. Retrieved from https://unctad.org/ meetings/es/SessionalDocuments/ares70d1_es.pdf

Yitzhaki, S. (1979). Relative deprivation and the Gini coefficient. Quarterly Journal of Economics, 93(2), 321-324.

Zalakain, H., \& Barragué, B. (2017). Repensar las políticas sociales: Pre distribución e inversión social. Madrid: Editorial grupo 5.

Open Access This chapter is licensed under the terms of the Creative Commons Attribution 4.0 International License (http://creativecommons.org/licenses/by/4.0/), which permits use, sharing, adaptation, distribution and reproduction in any medium or format, as long as you give appropriate credit to the original author(s) and the source, provide a link to the Creative Commons licence and indicate if changes were made.

The images or other third party material in this chapter are included in the chapter's Creative Commons licence, unless indicated otherwise in a credit line to the material. If material is not included in the chapter's Creative Commons licence and your intended use is not permitted by statutory regulation or exceeds the permitted use, you will need to obtain permission directly from the copyright holder.

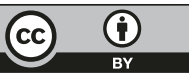

